\title{
Investigating the Effectiveness of Sport and Circulo Massages to Improve the Work Productiveness
}

\author{
SUMARJO*, AGUS KRISTIYANTO, ENDANG SUTISNA SULAEMAN, NOER RAHMA \\ Department of Sport Science \\ Faculty of Sport Science \\ Universitas Sebelas Maret \\ Surakarta, Jawa Tengah 57126 \\ INDONESIA
}

\begin{abstract}
Society's perception of people with different physical capabilities is that people with various physical capabilities might bring about nothing but catastrophe. Therefore, inclusive education implementation has related to society's problem perception should be improved. One way to improve the implementation of inclusive education is to pursue the development of the education system, evaluation system and career system to improve the productiveness so that the life quality might be better. In relation to the statement, the present study's objective is to identify the effectiveness of the sports massage and the circulo massage toward people productiveness with different physical capability based on the educational degree. During the study's conduct, the approach that had been adopted was the quasi-experimental approach with the factorial $2 \times 2$ design. The data were taken from the people with different physical capability who attended the training programs in the Integrated Rehabilitation Center for the People with Different Physical Capability. The samples were selected from the population by using the Purposive Sampling Technique. Then, in order to measure the productiveness, the researcher distributed a questionnaire to each sample. After the data had been gathered, the data were analysed using multivariate analysis with a significance level of 0.05 . The results of the study show that the massage method that has shown the greatest improvement for the work productiveness is the one that has the following sequence: (1) sports massage for with school education; (2) circulo massage without school education; (3) sports massage without school education; and (4) circulo massage with school education. As a result, it might be concluded that the sports massage method with the school education has been the most effective method for improving the work productiveness, which consists of motivation, knowledge, skills, attitude and independence.
\end{abstract}

Key-Words: - academic sport massage, Circulo massage, different physical capability and work productiveness

Received: February 18, 2021. Revised: July 1, 2021. Accepted: July 5, 2021. Published: July 9, 2021

\section{Introduction}

Nowadays, the Indonesian people have been striving to improve life quality and human resources quality as part of their continuous and advanced society. The knowledge and skills that have been mastered through education become the equipment for participating in the development activities, including their family [1]. The community health programs set a priority to improving the health of the community and the family, preventing diseases, and strengthening work productiveness [2]. Improving community health is given priority to enhance the quality of life through the community education initiative. In this case, both the family and the school's role become important as the manifestation of the aspiration formulated into the objectives of the national development. The manifestation of the well-qualified generation for the nation and the state development includes the people with different physical capability. Unfortunately, people with different physical capability are often isolated socially, and they even must deal with discrimination in terms of health access, educational service, and employment.

Law Number 36 of 2009 on Health includes physical, mental, social, spiritual, and economic. The statement implies that an individual's health is measured from the physical, mental, spiritual, and social aspects and from the productiveness aspects in the sense that the individual has employment or has economic input. In relation to the statement, people with different physical capabilities are defined as having incomplete body parts due to certain conditions such as amputation, bone disorder, muscular, joint disorder, elbow disorder, arm disorder, and paralysis. At the same time, WHO 
(2005) has calculated that the number of people with different physical capability has been $10.00 \%$ (24 million people) of the total Indonesian population. Furthermore, the data of PUSDATIN from the Ministry of Social Affairs showed the number of people with different capability for 2010 in Indonesia had been 11,580,117 people (48.25\%), consisting of 3,474,035 people with different visual capability (14.47\%), 3,010,830 people with different physical capability (12.54\%), 2,547,626 people with different auditory capability (10.61\%), 1,389,614 people with different mental capability (5.79\%) and $1,158,012$ people with chronically different capability (4.82\%).

Based on Sakernas 2017 in [3], the national figure of the working-age people with different capability has been $21,930,529$ people. From the total figure, the number of the people with different capability that belongs to the workforce is $11,224,673$ people $(51.18 \%)$. In comparison, the number of working people with different capability is $10,810,451$ people $(96.31 \%)$, and the number of openly unemployed people with different capability is 414,22 people $(3.69 \%)$. On the other hand, the number of people with different capabilities that do not belong to the workforce is $10,705,856$ people (48.82\%).

Furthermore, the number of people with different capability that pursue their schooling education is 206,163 people $(1.93 \%)$. The number of people with different capability deals with household caretaking activities is 5,911,017 people (55.21). The number of people with different capabilities assigned to other matters is 4,588,676 people $(42.86 \%)$. From these data, it is apparent that the national unemployment figure for people with different capability has been $3.69 \%$.

The government's role, the given institutions, and the experts of the people with different capability is still necessary for supporting the programs of unemployment eradication. The steps that have been intended for the improvement of the community capacity might empower more the people with the different capability in a sense that the people with the different capability will be able to perform something useful in the community development. People with different physical capabilities have the potentials and willingness to pursue a better course of life with the potential natural resources and local wisdom.

The training programs for people with different capabilities might be defined as the spark of new hope for better and more prosperous life quality. In several countries, the attention toward people with different capabilities has been enormous in skills training and development programs. For example, in Estonia a non-government organisation or NGO named "Helping Hand" has been actively establishing a partnership with other institutions such as "Think Estonia" and "Merimetsa Support Center" in order to provide training and education programs in the domain of handicraft for the people with different capacities. The "Helping Hand" NGO has also established an agreement with several companies in Estonia that demand workers for several light-type jobs.

In Indonesia, to develop the independence of the people with different capability has also been pursued. One way to pursue such independence is to establish entrepreneurship cooperation by involving several people with different physical capability. According to Tribun Jogja (Anonymous, 2016), a motorist transportation service labelled Dhifa CT (City Tour and Transport) is managed by people with different capabilities. This service is an institution of independence for people with different capabilities who want to prove that people with different capabilities can also penetrate the employment to eliminate the discrimination directed toward them in employment.

The Indonesian government has pursued the efforts of improving the work productiveness among people with different capability through the provision of numerous skills development programs [4]. For example, through the skills development programs in the Integrated Rehabilitation Center for the People with Different Physical Capability, the people with different physical capability are trained to master numerous skills. The term productiveness itself refers to the capacity of generating something. Then, to achieve a high level of productiveness, several factors support the high productiveness level of people with different physical capability. These supporting factors are namely: (1) education; (2) skills, (3) work ethics and attitudes; (4) income level; (5) social security; (6) social level and job atmosphere; (7) motivation; (8) health and nutrition; (9) individual relationship; (10) technology; and (11) production.

The results of the preliminary study from several pieces of research show that the samples that have been provided with the training programs have a better attitude after they attend the training programs [5]. In relation to Rudenko, Mahliovanyy, Shyyan \& Prystupa [6] state that the physical rehabilitation of the athletes with different capability through massage has been able to encourage the development of the compensation mechanism, to recover and improve the manipulative action capacity and also to recover the pathological 
conditions concerning the underlying and the related diseases. Physical rehabilitation facilities improve the implementation of the thermo-regulation process, stimulate the periphery vessel performance, improve the metabolism, and repair the regional blood flow [7]. Similarly, Sukamti, Elumalai, Siswantoyo, Saputra, Nugroho \& Nugroho [4] results show that massage therapy has been useful for students with different capabilities by repairing the short-term thinking patterns and long-term behaviour. On the other hand, a study by Purnama [8] shows that the cupping massage has not been more effective than progressive muscle relaxation in lessening non-specific chronic neck pain. However, both cupping massage and progressive muscle relaxation (PMR) might be easily performed in the house and might also lessen the pain at the low minimum clinical level. The only difference is that the cupping massage might be better than the PMR in improving the welfare and lessening the pain sensitivity. Despite the statement, there should be more studies with a higher number of samples and longer follow-up periods to confirm these findings.

Indeed, the provision of skills development programs for people with different capability is the fulfilment of the impending needs based on the potentials under possession, which might be improved toward independence. Through the skills development programs that have been intended toward the people with different capability, such as the provision of sports massage training programs and the circulo massage training programs, it is expected that the people with different capability can have a better life and eliminate the perception that the people with different capability will only be a life burden for the community by being beggars in certain places.

\section{Methodology}

The study was quantitative research using the quasiexperimental method. In the study, the treatment group was measured by providing the Sports Massage and the Circulo Massage technique with the distal and proximal direction toward improving the work productiveness among the people with the different physical capability. Then, within the conduct of the study, the factorial $2 \times 2$ design had been adopted. The population within the study was the people with the monoplegia physical capability who displayed the following characteristics: (i) Male, (ii) 20 - 30 years old, (iii) Having only one lower moving body part that had been paralysed and (iv) Used to attend the school and the non-school training programs in the Integrated Rehabilitation
Center for the People with Different Physical Capability in the District of Pundong, Regency of Bantul, Province of Yogyakarta Special Region

Furthermore, the samples within the study were selected from the existing population by means of the purposive random sampling technique. The sample size that should be taken was measured by using the Isaac \& Michael Formula [6]. On the other hand, the data were gathered by means of a questionnaire. The questionnaire as the instrument that had been implemented for measuring the work productiveness within the study consisted of five influencing factors, namely: (1) motivation; (2) knowledge; (3) skills; (4) attitudes; and (5) Independence. After the data had been gathered, the data analysis technique that had been adopted was the prerequisite test and the hypothesis test.

The prerequisite test that had been adopted was the Kolmogorov-Sminov Z. Next, the statistical tests that had been adopted for testing the variance homogeneity were the F-test, which compared the highest variance to the lowest variance, and the ttest, which aimed at identifying whether there had been variable differences in each group or not. For the hypothesis test, the multivariate analysis (MANOVA) using the Repeated Measure test was adopted to identify the differences between the dependent variables and the independent variables with the rate of significance higher than 0.05 .

\section{Results and Discussion}

\subsection{Results}

The study results displayed the data that had been relevant to the objective and the hypothesis of the study. The data display for the study results was in the form of tables, graphics, figures or charts that had been ordered following each sequence within the study's conduct. The data description, the hypothesis test prerequisite, and the hypothesis test results were elaborated through the data display. The data description elaborated on the data from the measurement results, which consisted of motivation, knowledge, skills, attitude and independence both before and after the provision of the massage training programs in each group. Simultaneously, the data description also contained the delta of each group for each dependent variable.

The delta means a score of each group provided with the massage training programs, namely the sport massage and the circulo massage training programs, for each variable might be consulted in Table 1 below. 
Table 1. Results of Overall Delta Mean Gain Score (\%)

\begin{tabular}{|l|c|c|c|c|}
\hline \multirow{2}{*}{ Variable } & \multicolumn{4}{|c|}{ Group } \\
\cline { 2 - 5 } & $\mathbf{1}$ & $\mathbf{2}$ & $\mathbf{3}$ & $\mathbf{4}$ \\
\hline Motivation & 85.98 & 25.09 & 39.25 & 54.76 \\
\hline Knowledge & 79.44 & 25.12 & 39.2 & 51.9 \\
\hline Skills & 76.2 & 28.1 & 39.9 & 52.5 \\
\hline Attitude & 77.24 & 25.31 & 38.97 & 51.28 \\
\hline Independence & 78.85 & 23.56 & 35.99 & 47.17 \\
\hline
\end{tabular}

Table 1 shows that both groups had enjoyed an improvement in each dependent variable. The improvement might be traced from the mean score, which displayed a positive value. In this section, each of the dependent variables was elaborated further for each group.

\section{a. Motivation}

This study found that Group 1 had the highest delta mean score (85.98). As a result, it might be concluded that the sports massage training program for the educated people with the different physical capability in Group 1 had been better in improving the motivation than the combined training programs for the other groups. The results of the delta mean score in each group might be consulted in Figure 1 below.

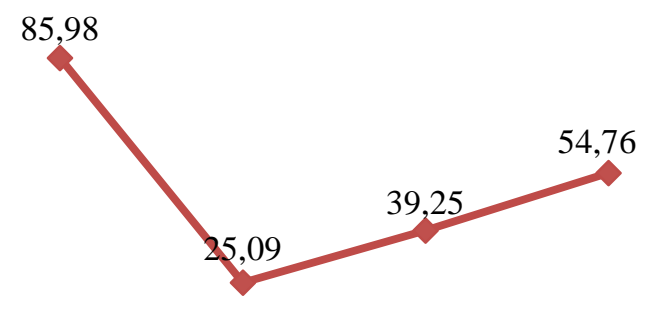

Fig.1: Results of Delta Mean Score for the Variable Motivation in Each Group

\section{b. Knowledge}

The variable knowledge found that Group 1 had the highest delta mean score (79.44). As a result, it might be concluded that the sports massage training program for the educated people with the different physical capability in Group 1 had been better in improving the knowledge in comparison to the combined training programs for the other groups. The results of the delta mean score in each group might be consulted in Figure 2 below.

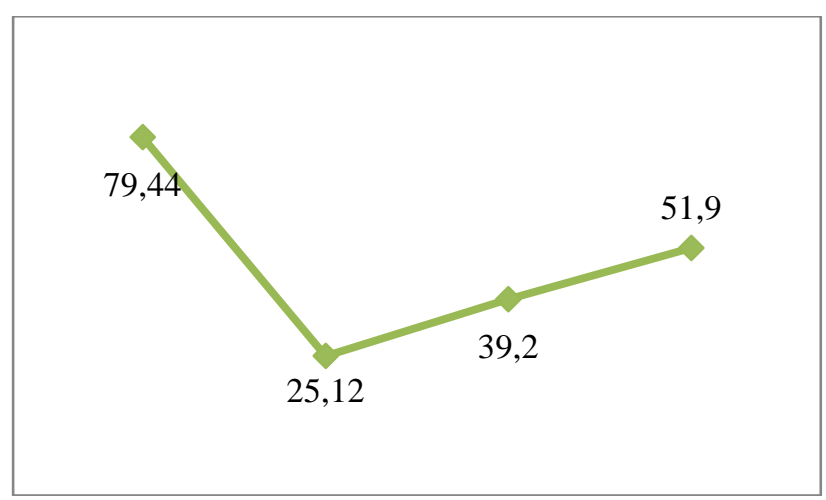

Fig.2: Results of Delta Mean Score for the Variable Knowledge in Each Group

\section{c. Skills}

The variable Skills found that Group 1 had the highest delta mean score (76.23). As a result, it might be concluded that the sports massage training program for the people with the educated different physical capability in Group 1 had improved the skills compared to the combined training programs for the other groups. The results of the delta mean score in each group might be consulted in Figure 3 below.

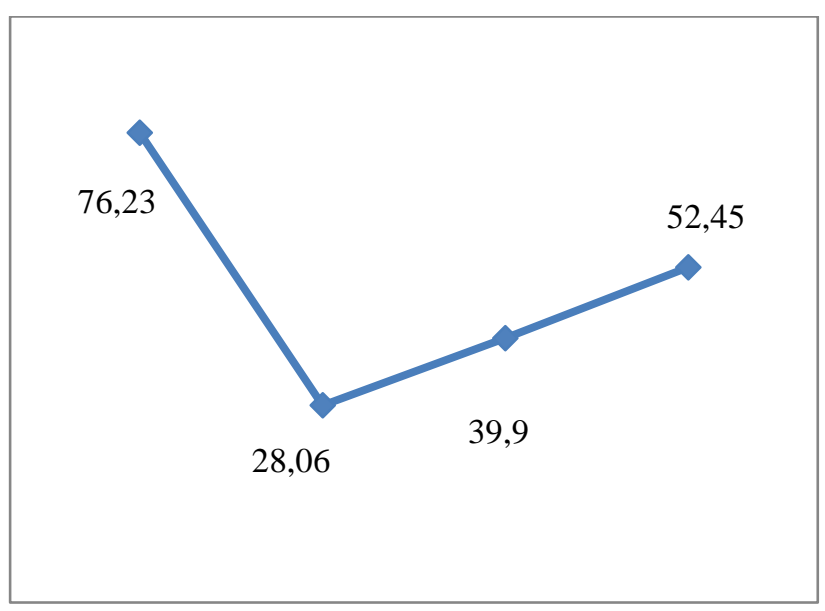

Fig.3: Results of Delta Mean Score for the Variable Skills in Each Group

\section{d. Attitude}

For the variable attitude, it was found that Group 1 had the highest delta mean score (77.24). As a result, it might be concluded that the sports massage training program for the educated people with the different physical capability in Group 1 had been better in improving the attitude in comparison to the combined training programs for the other groups. The results of the delta mean score in each group might be consulted in Figure 4 below. 


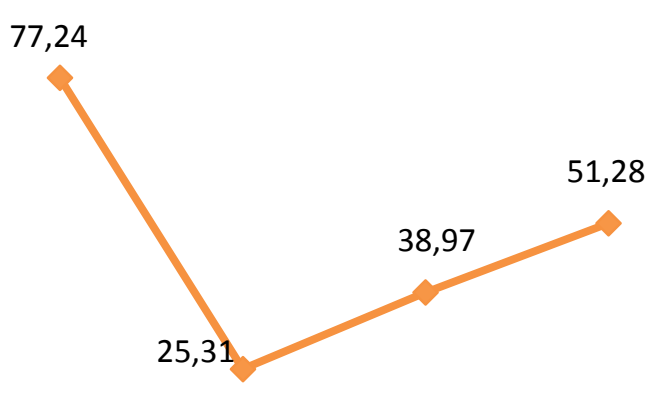

Fig.4: Results of Delta Mean Score for the Variable Attitude in Each Group

\section{e. Independence}

The variable independence found that Group 1 had the highest delta mean score (78.85). As a result, it might be concluded that the sports massage training program for the educated people with the different physical capability in Group 1 had improved the independence compared to the combined training programs for the other groups. The results of the delta mean score in each group might be consulted in Figure 5 below.

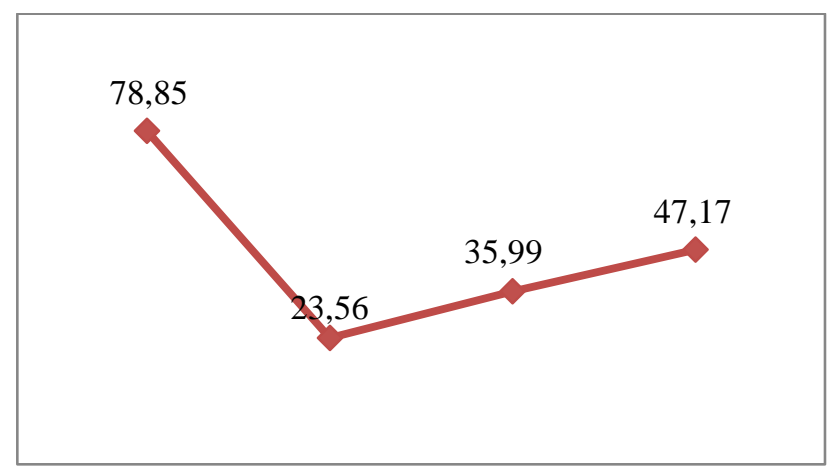

Fig.5: Results of Delta Mean Score for the Variable Independence in Each Group

\subsubsection{Prerequisite Testing}

The analysis prerequisite test was conducted prior to the analysis of the data that had been gathered by using the statistical parametric test. The analysis prerequisite that should be met within the factorial analysis was the covariance matrix box test. In other words, the box test is the prerequisite that should be met within the factorial analysis. The reason was that the box test results should be used as the basis for testing the assumption of the factorial analysis, which required that the variance matrix of the dependent variable should be the same (or similar). Therefore, in reading the data, the variance matrix of the dependent variable would have been equal if the p-value (sig.) $>0.05$. Then, the results of the box test within the study might be consulted in Table 2 below.

Table 2. Results of Box Test for the Post-Test Data

\begin{tabular}{|c|r|r|r|}
\hline $\begin{array}{c}\text { Box M } \\
\text { Test }\end{array}$ & F-count & $\boldsymbol{p}$ & Status \\
\hline 64.219 & 0.853 & 0.743 & Fulfilled \\
\hline
\end{tabular}

From the results of the box test, it was found the significance value $>0.05$. Therefore, it might be concluded that the variance matrix of the dependent variable had been equal. In other words, the box test results in the data had been in accordance with the assumption of the factorial test. Consequently, the reading toward the factorial test results might proceed.

\subsubsection{Hypothesis Testing}

Based on the results of the MANOVA analysis within the massage training method, it was found that the p-value $<0.05$ (sig. had been lower than 0.05). Consequently, the sport massage training method for the educated people with different physical capability (Cell 1), the sports massage training method for the non-educated people with different physical capability (Cell 2), the circulo massage training method for the educated people with different physical capability (Cell 3) and the circulo massage training method for the noneducated people with different physical capability (Cell 4) should be analysed by using four statistical models namely: (1) Pillai's Trace; (2) Wilks' Lambda; (3) Hotelling's Trace; and (4) Roy's Largest Root. The results of the analysis by means of the four statistical models showed that the significance value had been equal to 0.000 or lower than $0.050(\mathrm{p}<0.05)$. Therefore, it might be stated that the sports massage training method for the educated people with different physical capacity (Cell 1), the sports massage training method for the non-educated people with different physical capacity (Cell 2), the circulo massage training method for the educated people with different physical capacity (Cell 3) and the circulo massage training method for the non-educated people with different physical capacity (Cell 4) had significant influence toward the improvement of the work productiveness, which consisted of motivation, knowledge, skills, attitude and independence. The results of the multivariate analysis might be consulted in Table 3 below. 
Table 3. Results of Multivariate Test

\begin{tabular}{|c|c|c|c|c|}
\hline \multicolumn{2}{|c|}{ Effect } & Value & $\mathrm{F}$ & Sig. \\
\hline \multirow{4}{*}{ Intercept } & $\begin{array}{l}\text { Pillai's } \\
\text { Trace }\end{array}$ & 0.996 & $949.577^{b}$ & 0.000 \\
\hline & $\begin{array}{l}\text { Wilks' } \\
\text { Lambda }\end{array}$ & 0.004 & $949.577^{\mathrm{b}}$ & 0.000 \\
\hline & $\begin{array}{l}\text { Hotelling's } \\
\text { Trace }\end{array}$ & 237.394 & $949.577^{b}$ & 0.000 \\
\hline & $\begin{array}{l}\text { Roy's } \\
\text { Largest } \\
\text { Root }\end{array}$ & 237.394 & $949.577^{b}$ & 0.000 \\
\hline \multirow{4}{*}{ Massage } & $\begin{array}{l}\text { Pillai's } \\
\text { Trace }\end{array}$ & 0.580 & $5.523^{\mathrm{b}}$ & 0.002 \\
\hline & $\begin{array}{l}\text { Wilks' } \\
\text { Lambda }\end{array}$ & 0.420 & $5.523^{\mathrm{b}}$ & 0.002 \\
\hline & $\begin{array}{l}\text { Hotelling's } \\
\text { Trace }\end{array}$ & 1.381 & $5.523^{\mathrm{b}}$ & 0.002 \\
\hline & $\begin{array}{l}\text { Roy's } \\
\text { Largest } \\
\text { Root }\end{array}$ & 1.381 & $5.523^{\mathrm{b}}$ & 0.002 \\
\hline \multirow{4}{*}{ Education } & $\begin{array}{l}\text { Pillai's } \\
\text { Trace }\end{array}$ & 0.913 & $41.757^{\mathrm{b}}$ & 0.000 \\
\hline & $\begin{array}{l}\text { Wilks' } \\
\text { Lambda }\end{array}$ & 0.087 & $41.757^{\mathrm{b}}$ & 0.000 \\
\hline & $\begin{array}{l}\text { Hotelling's } \\
\text { Trace }\end{array}$ & 10.439 & $41.757^{\mathrm{b}}$ & 0.000 \\
\hline & $\begin{array}{l}\text { Roy's } \\
\text { Largest } \\
\text { Root }\end{array}$ & 10.439 & $41.757^{\mathrm{b}}$ & 0.000 \\
\hline \multirow{4}{*}{$\begin{array}{l}\text { Massage * } \\
\text { Education }\end{array}$} & $\begin{array}{l}\text { Pillai's } \\
\text { Trace }\end{array}$ & 0.964 & $108.498^{b}$ & 0.000 \\
\hline & $\begin{array}{l}\text { Wilks' } \\
\text { Lambda }\end{array}$ & 0.036 & $108.498^{\mathrm{b}}$ & 0.000 \\
\hline & $\begin{array}{l}\text { Hotelling's } \\
\text { Trace } \\
\text { Roy's }\end{array}$ & 27.125 & $108.498^{\mathrm{b}}$ & 0.000 \\
\hline & $\begin{array}{l}\text { Largest } \\
\text { Root }\end{array}$ & 27.125 & $108.498^{b}$ & 0.000 \\
\hline
\end{tabular}

The detailed elaboration for each cell to calculate the size of the influence improvement for the significance of the dependent variables, which consisted of motivation, knowledge, skills, attitude and independence, might be consulted in Table 4 below.

Table 4. Results of Estimates

\begin{tabular}{|c|c|c|c|c|}
\hline $\begin{array}{c}\text { Dependent } \\
\text { Variable }\end{array}$ & $\begin{array}{l}\text { Massage } \\
\text { Training }\end{array}$ & $\begin{array}{l}\text { Educational } \\
\text { Background }\end{array}$ & Mean & $\begin{array}{l}\text { Std. } \\
\text { Error }\end{array}$ \\
\hline \multirow{4}{*}{ Motivation } & \multirow{2}{*}{$\begin{array}{l}\text { Sport } \\
\text { massage }\end{array}$} & Educated & 85.9800 & 3.13648 \\
\hline & & $\begin{array}{l}\text { Non- } \\
\text { Educated }\end{array}$ & 25.0971 & 3.68111 \\
\hline & \multirow{2}{*}{$\begin{array}{l}\text { Circulo } \\
\text { massage }\end{array}$} & Educated & 39.2514 & 3.27310 \\
\hline & & $\begin{array}{l}\text { Non- } \\
\text { Educated }\end{array}$ & 54.7600 & 4.08906 \\
\hline \multirow{3}{*}{ Knowledge } & \multirow{2}{*}{$\begin{array}{l}\text { Sport } \\
\text { massage }\end{array}$} & Educated & 79.4443 & 1.74461 \\
\hline & & $\begin{array}{l}\text { Non- } \\
\text { Educated }\end{array}$ & 25.1257 & 3.66258 \\
\hline & Circulo & Educated & 39.2071 & 3.31112 \\
\hline
\end{tabular}

\begin{tabular}{|c|c|c|c|c|}
\hline & massage & $\begin{array}{l}\text { Non- } \\
\text { Educated }\end{array}$ & 51.9000 & 2.84251 \\
\hline \multirow{4}{*}{ Skills } & \multirow{2}{*}{$\begin{array}{l}\text { Sport } \\
\text { massage }\end{array}$} & Educated & 76.2329 & 2.97688 \\
\hline & & $\begin{array}{l}\text { Non- } \\
\text { Educated }\end{array}$ & 28.0600 & 2.58830 \\
\hline & \multirow{2}{*}{$\begin{array}{l}\text { Circulo } \\
\text { massage }\end{array}$} & Educated & 39.9043 & 3.15189 \\
\hline & & $\begin{array}{l}\text { Non- } \\
\text { Educated }\end{array}$ & 52.4543 & 2.11767 \\
\hline \multirow{4}{*}{ Attitude } & \multirow{2}{*}{$\begin{array}{l}\text { Sport } \\
\text { massage }\end{array}$} & Educated & 77.2486 & 2.04099 \\
\hline & & $\begin{array}{l}\text { Non- } \\
\text { Educated }\end{array}$ & 25.3114 & 2.99241 \\
\hline & \multirow{2}{*}{$\begin{array}{l}\text { Circulo } \\
\text { massage }\end{array}$} & Educated & 38.9771 & 2.71166 \\
\hline & & $\begin{array}{l}\text { Non- } \\
\text { Educated }\end{array}$ & 51.2871 & 3.36785 \\
\hline \multirow{4}{*}{ Independence } & \multirow{2}{*}{$\begin{array}{l}\text { Sport } \\
\text { massage }\end{array}$} & Educated & 78.8500 & 3.62450 \\
\hline & & $\begin{array}{l}\text { Non- } \\
\text { Educated }\end{array}$ & 23.5671 & 1.65501 \\
\hline & \multirow{2}{*}{$\begin{array}{l}\text { Circulo } \\
\text { massage }\end{array}$} & Educated & 35.9957 & 2.62435 \\
\hline & & $\begin{array}{l}\text { Non- } \\
\text { Educated }\end{array}$ & 47.1757 & 2.73162 \\
\hline
\end{tabular}

Based on the results of the MANOVA analysis, and from the results of Estimates Marginal Means within the implementation of the sports massage and the Circulo massage training method among the educated and the non-educated people with a different physical test, it might be concluded to improve the work productiveness, which consisted of motivation, knowledge, skills, attitude and independence, the most effective method had been found in the Cell 1.1 namely the sports massage training method for the educated people with different physical capabilities. The summary of the lower bound from the 4 (four) cells based on the confidence interval might be consulted in Table 5 below.

Table 5. Summary of the Lower Bound from the 4 (Four) Cells

\begin{tabular}{clcc}
\hline \multirow{2}{*}{$\begin{array}{c}\text { Massage } \\
\text { Method }\end{array}$} & $\begin{array}{c}\text { Dependent } \\
\text { Variable }\end{array}$ & \multicolumn{2}{c}{ Educational Background } \\
\cline { 3 - 4 } & & $\begin{array}{c}\text { Educated } \\
\text { bower }\end{array}$ & $\begin{array}{c}\text { Uneducated } \\
\text { bound } \\
\text { bound }\end{array}$ \\
\hline \multirow{3}{*}{ Sport } & Motivation & 78.3053 & 16.0898 \\
Massage & Knowledge & 75.1754 & 16.1637 \\
& Skills & 68.9487 & 21.7267 \\
& Attitude & 72.2544 & 17.9893 \\
& Independence & 69.9812 & 19.5175 \\
& Motivation & 31.2424 & 44.7544 \\
Circulo & Knowledge & 31.1051 & 44.9446 \\
Massage & Skills & 32.1919 & 47.2725 \\
& Attitude & 32.3419 & 43.0463 \\
& Independence & 29.5742 & 40.4917 \\
\hline
\end{tabular}

\subsection{Discussion}

The study results show that there has been significant influence from the sports massage training method for the educated people with different physical capability toward improving work 
productiveness, which consists of motivation, knowledge, skills, attitude and independence. The sports massage training method, which has been conducted in 24 intensive meetings for 8 consecutive weeks, can improve the components of the work produced at the minimum rate (lower bound) with the following details: (1) motivation (78.3053); (2) knowledge (75,1754); (3) skills (68,9487); (4) attitude (72.2544); and (5) Independence (69.9812). In relation to the provision of the sports massage training method, educated people with different physical capability as the treatment group show the greatest improvement of work productiveness in all variables.

From the results of the study, it might be concluded that the most effective massage training method for improving work productiveness is the sports massage method for educated people with different physical capability. The Board of National Productiveness defines that productiveness refers to the mental attitude, which always views that today's quality of life should be better than the quality of life yesterday. The quality of life tomorrow should be better than the quality of life today. The philosophy and the spirit of productiveness have been in existence since the beginning of human civilisation since the meaning of productiveness refers to the will and the effort of humankind in continuously improving life and living in all domains. In general, productiveness refers to comparing the output that has been achieved and the input that has been demanded to generate the output [8]. Diana [9] stated that numerous factors that influence the work productiveness are, for example, a mental attitude which consists of work motivation, work discipline and ethics, education, skills, management, income level, health, social security, social environment, work atmosphere, production facility, technology and achievement opportunity.

The study results show that the differences between the sports massage training method and the Circulo massage training method might affect the work productiveness, consisting of motivation, knowledge, attitude, skills and independence. In line with the study results by Li, Zhou, Zhang, Qi, Sun, $\mathrm{Xu} \&$ Wang [10], the study found that the massage technique applied is very useful for dealing with health problems, pain complaints, and fatigue. Massage is an enjoyable thing because massage can help both the body and the soul produce endorphin, which is a natural painkiller for the body [11]. Li, Zhou, Zhang, Qi, Sun, Xu \& Wang [10] argues that massage has a mechanical impact that will repair the blood circulation, eliminate the waste product from the body, improve joint mobility, and decrease muscle strain. Wahida \& Khusniyah [12] state that massage application will influence the cerebral cortex's performance so that the positive perception and the relaxation are produced, which indirectly assist the maintenance of the balance of the body homeostasis through the part of HPA Axis to generate the Corticotrophin Releasing Factor (CRF).

Sport massage has numerous manipulations namely: (1) effleurage; (2) petrissage; (3) shaking; (4) tapotement; (5) friction; (6) walking; (7) vibration; (8) stroking; (9) skin-rolling; and (10) chiropractic. With these manipulations, the sports massage can generate several hormones such as (1) endorphin, (2) adrenaline, and (3) thyroxin. The endorphin hormone, which might be categorised as a soothing hormone, is attained by applying effleurage and friction manipulation. Then, the thyroxin hormone, which aims to transport them away from the leftover of the body metabolism, is attained from applying the petrissage, tapotement, effleurage, shaking, and walking manipulation. Finally, the adrenaline hormone, which aims at controlling the nerve system, is attained through the application of tapotement manipulation. Specific to the statement, the sports massage can also stimulate the peripheral nerves [2], [13].

On the other hand, the circulo massage training method's mainstay technique is circular movementbased friction. In relation to the statement, the tapotement manipulation is intended to maximise the friction application results, while the effleurage manipulation is intended to provide a soothing effect. At the beginning of the massage, friction manipulation is directly applied since the intention is to provide the shocking effect and stimulate the release of the endorphin hormone, which serves as a sedative. All body parts from the palm to the head will be manipulated to apply the Circulo massage under consideration toward the muscle structure and the organ procedures. The manipulation itself, or also known as the grip, refers to using the hands in performing the Circulo massage toward certain areas and exerting certain influence. The types of manipulation in the Circulo massage are namely: (1) friction; (2) tapotement; (3) walking; (4) effleurage; and (5) skin-rolling [14].

Eventually, the study results show that there have been significant differences between the educated and the non-educated people with different physical capability toward the improvement of the work productiveness, which consists of motivation, knowledge, skills, attitude and independence. Through numerous studies, it has been proposed that the samples which have been provided with the training programs display a better attitude [5]. In 
relation to Nugroho \& Asrin [15], stated that the massage that has been performed regularly can decrease both the systolic and the diastolic blood pressure, the rate of the stress hormone cortisol and the sources of depression and anxiety so that the blood pressure will continue to decrease and thus the function of the body organs might improve. If the body organs' functions improve, then both life quality and the work productiveness might improve as well.

\section{Conclusions}

In conclusion, the effectiveness of the sports massage and the Circulo massage training method based on the education level of the people with the different physical capability to improve the work productiveness, it is found that the massage method that has the greatest level of improvement for the work productiveness has been ordered in the following sequence: (1) sports massage for the educated people with different physical capacity; (2) Circulo massage for the non-educated people with different physical capacity; (3) sports massage for the non-educated people with different physical capacity; and (4) Circulo massage for the educated people with different physical capabilities. Therefore, it might be concluded that the sports massage training method for the educated people with different physical capacity has been the most effective method for improving the work productiveness, which consists of motivation, knowledge, skills, attitude and independence.

\section{Acknowledgements:}

The researchers would like to thank the study's promotor and the colleagues who have provided useful assistance during the study's conduct so that the study might be completed following the already designated timeline. Besides, the researchers would like to thank the Faculty of Sports Science, who has authorised using the necessary facilities until the end of the study's conduct.

\section{References:}

[1] Sujarwo, S. Suharjana, H. A. Rachman, S. Siswantoyo, and J. Saputra, "Identifying the factor structure of physical education learning model and its effectiveness in improving the character values of students," J. Adv. Res. Dyn. Control Syst., vol. 12, no. 6, pp. 766-775, 2020.

[2] Nashrullah, F.F., W. M. Radzi, S. Siswantoyo, and J. Saputra, "A study of sport-related legal provisions and regulations among elite student-athlete and staff in Yogyakarta public universities, Indonesia," J. Adv. Res. Dyn. Control Syst., vol. 12, no. 6, pp. 751-756, 2020.

[3] Nurahman, A., Widodo, W., Ishafit, I., \& Saulon, B. O., "The development of worksheet based on guided discovery learning method helped by phet simulations interactive media in newton's laws of motion to improve learning outcomes and interest of vocational education 10th grade students.," Indones. Rev. Phys., vol. 1, no. 2, pp. 37-41, 2018.

[4] Sukamti, E.R. Elumalai, G. Siswantoyo,. Saputra, J. Nugroho, W. \& Nugroho, A., "Technological innovation with visual and auditory stimulus: Testing the validity and reliability of smart WBRT 515-GM," J. Adv. Res. Dyn. Control Syst., vol. 12, no. 6, pp. 745-750, 2020.

[5] MacLaren, J. E., Cohen, L. L., Larkin, K. T., \& Shelton, E. N., "Training nursing students in evidence-based techniques for cognitivebehavioral pediatric pain management," $J$. Nurs. Educ., vol. 47, no. 8, pp. 351-358, 2008.

[6] Rudenko, R., Mahliovanyy, A., Shyyan, O., \& Prystupa, T., "Physical rehabilitation and thermoregulatory processes in athletes with disabilities," J. Phys. Educ. Sport, vol. 15, no. 4 , pp. 730-735, 2015, doi: 10.7752/jpes.2015.04111.

[7] Sukamti, E.R., Saputra, J. \& Sugiharto., "Study of Sprint and Vertical Jump for Indonesian Athletes: Multi-Sectorial Testing/Estudio de carrera corta y salto vertical para atletas indonesios: pruebas," Utopía y Prax. Latinoam., vol. 25, no. S10, pp. 419-429, 2020, Accessed: Mar. 02, 2021. [Online]. Available: https://go.gale.com/ps/i.do?id=GALE\%7CA $649933020 \&$ sid $=$ googleScholar\&v=2.1\&it=r \&linkaccess $=$ abs \&issn $=13165216 \& p=I F M E$ $\& \mathrm{sw}=\mathrm{w}$.

[8] Purnama, R., "Pengaruh Motivasi Kerja Terhadap Produktivitas Kerja Karyawan Pada Bagian Produksi CV. Epsilon Bandung," 2008.

[9] Diana, R., "Sumber Daya Manusia Dan Produktivitas Kerja," Jurnal Istinbath. .

[10] Li, X., Zhou, K., Zhang, E., Qi, Z., Sun, W., $\mathrm{Xu}, \mathrm{L} .$, ... \& Wang, R., "Therapeutic effect of electroacupuncture, massage, and blocking therapy on external humeral epicondylitis," J. Tradit. Chinese Med., vol. 
34, no. 3, pp. 261-266.

[11] Juliantri, V., Nurfianti, A., \& Maulana, M.A., "Efektivitas Massage Ekstremitas terhadap Perubahan Tekanan Darah pada Pasien Hipertensi di Klinik Pratama Universitas Tanjungpura Tahun 2015,” 2015.

[12] Wahida, N. \& Khusniyah, Z., "Pengaruh Hipnoterapi Terhadap Nyeri SendiPada Lansia," 2012.

[13] Kristiyanto, A., Sulaeman, E. S., \& Rahma, N., "The Effect of Sport and Circulo Massage on the Improvement of Work Productivity of the Physically Disabled.," 2018.

[14] Kushartanti, W., "Pelatihan Circulo Massage," Klinik Terapi Fisik Fakultas Ilmu Keolahragaan Universitas Negeri Yogyakarta, 2003.

[15] Nugroho, I. A., \& Asrin, S., "Efektifitas pijat refleksi kaki dan hipnoterapi terhadap penurunan tekanan darah pada pasien hipertensi," J. Ilm. Kesehat. Keperawatan, vol. 8, no. 2, p. 57, 2012.

Contribution of individual authors to the creation of a scientific article (ghostwriting policy)

Sumarjo writing - original draft, investigation and supervision.

Agus Kristiyanto writing - original draft and investigation, editing and revision.

Endang Sutisna Sulaeman writing - original draft and investigation, supervision.

Noer Rahma writing - original draft, editing, investigation and supervision.

Sources of funding for research presented in a scientific article or scientific article itself

This research funded by Universitas Sebelas Maret, Surakarta, Jawa Tengah 57126, Indonesia.

\section{Creative Commons Attribution License 4.0}

(Attribution 4.0 International, CC BY 4.0)

This article is published under the terms of the Creative Commons Attribution License 4.0

https://creativecommons.org/licenses/by/4.0/deed.en _US 